\title{
Cr-resistant rhizo- and endophytic bacteria associated with Prosopis juliflora and their potential as phytoremediation enhancing agents in metal-degraded soils
}

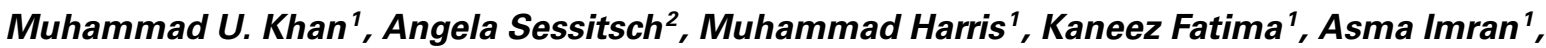 \\ Muhammad Arslan ${ }^{1,3}$, Ghulam Shabir ${ }^{1}$, Qaiser M. Khan ${ }^{1}$ and Muhammad Afzal ${ }^{1 *}$
}

\author{
${ }^{1}$ Environmental Biotechnology Division, National Institute for Biotechnology and Genetic Engineering, Faisalabad, Pakistan \\ ${ }^{2}$ Bioresources Unit, Austrian Institute of Technology GmbH, Tulln, Austria \\ ${ }^{3}$ Earth Sciences Department, King Fahd University of Petroleum and Minerals, Dhahran, Saudi Arabia
}

\section{Edited by:}

Antonella Furini, University of

Verona, Italy

Reviewed by:

Wusirika Ramakrishna, Michigan

Technological University, USA

Maria Lourdes Gil Cardeza, Consejo

Nacional de Investigaciones

Científicas y Técnicas, Argentina

${ }^{*}$ Correspondence:

Muhammad Afzal, Environmental

Biotechnology Division, National

Institute for Biotechnology and

Genetic Engineering, PO Box 577 ,

Jhang Road, Faisalabad 38000,

Pakistan

e-mail:manibge@yahoo.com

afzal@nibge.org
Prosopis juliflora is characterized by distinct and profuse growth even in nutritionally poor soil and environmentally stressed conditions and is believed to harbor some novel heavy metal-resistant bacteria in the rhizosphere and endosphere. This study was performed to isolate and characterize Cr-resistant bacteria from the rhizosphere and endosphere of $P$. juliflora growing on the tannery effluent contaminated soil. A total of 5 and 21 bacterial strains were isolated from the rhizosphere and endosphere, respectively, and were shown to tolerate $\mathrm{Cr}$ up to $3000 \mathrm{mg} \mathrm{I}^{-1}$. These isolates also exhibited tolerance to other toxic heavy metals such as, $\mathrm{Cd}, \mathrm{Cu}, \mathrm{Pb}$, and $\mathrm{Zn}$, and high concentration $(174 \mathrm{~g}$ $\mathrm{I}^{-1}$ ) of $\mathrm{NaCl}$. Moreover, most of the isolated bacterial strains showed one or more plant growth-promoting activities. The phylogenetic analysis of the $16 \mathrm{~S}$ rRNA gene showed that the predominant species included Bacillus, Staphylococcus and Aerococcus. As far as we know, this is the first report analyzing rhizo- and endophytic bacterial communities associated with $P$. juliflora growing on the tannery effluent contaminated soil. The inoculation of three isolates to ryegrass (Lolium multiflorum L.) improved plant growth and heavy metal removal from the tannery effluent contaminated soil suggesting that these bacteria could enhance the establishment of the plant in contaminated soil and also improve the efficiency of phytoremediation of heavy metal-degraded soils.

Keywords: Prosopis juliflora, heavy metals, phytoremediation, Cr-resistant bacteria, plant growth-promoting bacteria, rhizobacteria, endophytic bacteria

\section{INTRODUCTION}

Soil contamination by chromium and other toxic heavy metals has been a major problem worldwide. Among other industries, tanneries belong to the main contributors of soil and water contamination with $\mathrm{Cr}$ and other toxic heavy metals (Tariq et al., 2008; Rajkumar et al., 2012; Reichman, 2014). The presence of Cr and other toxic heavy metals in the environment could be highly toxic to human health (Chen et al., 2010; Ma et al., 2011; Sagar et al., 2012; Gil-Cardeza et al., 2014).

A number of woody plant species can grow on heavy metal polluted soil and are known as indicators of heavy metal pollution in the soil (Capuana, 2011). Prosopis juliflora, (Sw.) DC, a multipurpose perennial tree native to South America (Sajjad et al., 2012), was also studied as a possible bioindicator of soil pollution (Senthilkumar et al., 2005). In many parts of the world it is a wellknown plant species for its use as a fuel, shade, timber and forage. It is a deep rooted bush or tree and widely propagated in Asia, particularly in India and Pakistan (Deans et al., 2003; Benata et al., 2008; Qureshi et al., 2014). Furthermore, it remediates soil contaminated with heavy metals and helps in site reclamation (Jamal, 2006; Usha et al., 2009; Varun et al., 2011). During an initial survey of the tannery effluent contaminated area of Kasur (Punjab,
Pakistan), which is one of the most polluted areas by heavy metals in the world, only P. juliflora has been found to grow on the contaminated area with heavy metal high concentrations $(\mathrm{Cd}, 26 \mathrm{mg}$ $\mathrm{kg}^{-1}$; Co $22 \mathrm{mg} \mathrm{kg}^{-1}$; Cr, $2243 \mathrm{mg} \mathrm{kg}-1$;, $137 \mathrm{mg} \mathrm{kg}{ }^{-1}$; Mn $9.4 \mathrm{mg} \mathrm{kg}^{-1} ; \mathrm{Ni}, 34 \mathrm{mg} \mathrm{kg}^{-1} ; \mathrm{Pb}, 18 \mathrm{mg} \mathrm{kg}^{-1} ; \mathrm{Zn}, 14 \mathrm{mg} \mathrm{kg}^{-1}$ ) (Afzal et al., 2014a). Thus, there is a need for the soil in that area to be remediated and to make it usable again.

The combined use of plants and heavy metal-resistant plant growth-promoting bacteria is a promising approach for the remediation of heavy metal contaminated soil (Ma et al., 2009; Rajkumar et al., 2012; Sessitsch et al., 2013; Reichman, 2014). Rhizobacteria colonize in the close vicinity of roots whereas endophytic reside within the plant tissues (Afzal et al., 2014b). These bacteria may reduce the toxicity of heavy metals in soil and plant due to their metal-resistance and bioaccumulation potential (Gadd, 2010; Sessitsch et al., 2013; Zhu et al., 2014). Moreover, they may improve plant growth and development in a contaminated soil due to different plant growth-promoting activities (Glick, 2010; Sessitsch et al., 2013; Andrades-Moreno et al., 2014).

Better knowledge of the type of bacteria colonizing the rhizosphere and endosphere of the plants growing on heavy 
metal contaminated soil is important, however, rhizosphere and endophytic bacterial communities associated with $P$. juliflora have not been investigated so far. The aim of this study was to (i) explore the type of Cr-resistant rhizosphere and endophytic bacteria associated with $P$. juliflora, growing on the tannery effluent contaminated soil, (ii) and to study the effect of inoculation of three isolates to enhance plant growth and accumulation of heavy metals in the root and shoot of ryegrass vegetated in the tannery effluent contaminated soil.

\section{MATERIALS AND METHODS PLANT MATERIAL AND SOIL SAMPLING}

Plants of $P$. juliflora were collected in July 2013 from the site located in the surrounding of tanneries of Kasur $\left(31^{\circ} 0.7^{\prime} \mathrm{N}\right.$. $\left.74^{\circ} 0.27^{\prime} \mathrm{E}\right)$. Rhizosphere soil was collected from three different plants. Plants were carefully dug out with an intact root system and the soil tightly adhering to the roots was collected. The rhizosphere soil was obtained by agitating roots and sampling the soil still attach to the roots. No vegetation was observed in the bulk soil. Bulk soil samples were collected from three different points which were $100 \mathrm{ft}$ away from the vegetation. The shoots of three $P$. juliflora plants were cut from the roots at the collar diameter.

\section{ISOLATION AND CHARACTERIZATION OF Cr-RESISTANT RHIZO- AND ENDOPHYTIC BACTERIA}

Cr-resistance endophytic bacteria were isolated from the root and shoot of $P$. juliflora as described earlier (Zhu et al., 2014). Briefly, the roots and shoots were carefully washed and surface sterilized with $70 \%$ ethanol and $1 \%$ bleach. Subsequently, $3 \mathrm{~g}$ surface sterilized shoots or roots were homogenized with a pestle and mortar in $10 \mathrm{ml} \mathrm{NaCl}(0.9 \%$, w/v) solution. The homogenized material was agitated for $1 \mathrm{~h}$ at $30^{\circ} \mathrm{C}$. After settling of solid material, serial dilutions up to $10^{-2}$ were plated onto solid LB medium containing $100 \mathrm{mg} \mathrm{l}^{-1} \mathrm{Cr}$ as $\mathrm{Cr}_{2}\left(\mathrm{SO}_{4}\right)_{3}$. In an earlier study, a relatively low number of rhizosphere bacteria was obtained due to the presence of $\mathrm{Cr}$ above $100 \mathrm{mg} \mathrm{l}^{-1}$ (Abou-Shanab et al., 2005), therefore, in this study, $100 \mathrm{mg} \mathrm{l}^{-1}$ $\mathrm{Cr}$ concentration was used to obtain maximum number of $\mathrm{Cr}$ resistant bacteria. Several studies showed that metals influence microorganisms by adversely affecting their growth, morphology and biochemical activities, resulting in a decrease in their biomass and numbers (Giller et al., 1998; Abou-Shanab et al., 2005). Crresistant rhizosphere bacteria were obtained as described earlier (Kuffner et al., 2008). The soil slurry was prepared by mixing $4 \mathrm{~g}$ soil with $12 \mathrm{ml}$ of $0.9 \% \mathrm{NaCl}$ solution, agitated for $1 \mathrm{~h}$ at $30^{\circ} \mathrm{C}$. After the settlement of soil particles, serial dilutions up to $10^{-3}$ were plated onto LB media containing $\mathrm{Cr} 100 \mathrm{mg}$ $1^{-1}$. Colonies with different morphologies were picked out and purified by re-streaking onto the same medium at least three times.

On the basis of cell morphology, 78 different morphotypes were identified. A restriction fragment length polymorphism (RFLP) analysis of the 16S-23S rRNA intergenic spacer (IGS) region was performed to distinguish these 78 different bacterial morphotypes (Rasche et al., 2006; Yousaf et al., 2010a). On the basis of RFLP analysis, 26 different patterns
(IGS-type) were obtained (Mastretta et al., 2009). A representative isolate of each IGS type was identified by partial $16 \mathrm{~S}$ rRNA gene sequencing. 16S rRNA genes were amplified by using PCR primers of (5'-AGAGTTTGATCCTGGCTCAG$\left.3^{\prime}\right)$ and 1520 rev (5'-AAGGAGGTGATCCAGCCGGA-3') as explained earlier (Rasche et al., 2006; Yousaf et al., 2010b). The PCR amplification products were sequenced by the Macrogen (Seoul, Korea) with $8 \mathrm{f}$ and $1520 \mathrm{rev}$ primers. The sequences were compared with sequences in the GenBank database using NCBI Blast program (http://blast.ncbi.nlm.nih.gov/Blast.cgi). Sequences were submitted to GenBank database under accession numbers KJ933397-KJ933406, KJ999602-KJ999614, KM067905KM067907. In addition, the isolated rhizosphere and endophytic bacterial strains were deposited in the NIBGE Biological Resource Centre (NBRC).

\section{HEAVY METAL ANALYSIS OF SOIL AND PLANT SAMPLES}

For soil analysis, the samples (in three independent replicates) were air-dried, sieved, and $0.3 \mathrm{~g}$ soil digested with 1:1 concentrated $\mathrm{HNO}_{3}-\mathrm{H}_{2} \mathrm{SO}_{4}$. After cooling, the volume was made up to $100 \mathrm{ml}$ with double de-ionized water. For plant analysis, separately, $10 \mathrm{~g}$ dried roots and shoots were ground to pass through $0.2 \mathrm{~mm}$ sieve and digested ( $1 \mathrm{~g}$ of each) with mixture of sulfuric acid $\left(\mathrm{H}_{2} \mathrm{SO}_{4}\right)$, nitric acid $\left(\mathrm{HNO}_{3}\right)$ and perchloric acid $\left(\mathrm{HClO}_{4}\right)$ (Afzal et al., 2014c). The digested soil and plant samples were analyzed by inductively coupled plasma optical mission spectrometry (ICP-OES) for different heavy metals.

\section{Cr-RESISTANCE BY THE RHIZO- AND ENDOPHYTIC BACTERIA}

To determine the Cr-resistance of the isolated rhizosphere and endophytic bacteria, $100 \mu \mathrm{l}$ of overnight grown cultures were streaked on LB agar media containing $\mathrm{Cr} 500,1000,2000$, and $3000 \mathrm{mg} \mathrm{L}^{-1}$ as $\mathrm{Cr}_{2}\left(\mathrm{SO}_{4}\right)_{3}$. In this study, the concentration of $\mathrm{Cr}$ in the rhizosphere and bulk soil was 2542 and $2243 \mathrm{mg} \mathrm{kg}^{-1}$, respectively, therefore, isolated bacterial strains were tested at different concentrations of $\mathrm{Cr}$ up to $3000 \mathrm{mg} \mathrm{l}^{-1}$ for their possible application in the phytoremediation of tannery effluent contaminated soil. All the plates were incubated at $37^{\circ} \mathrm{C}$ for 2 days and observed for the appearance of bacterial growth. The resistance was expressed as the maximum tolerable concentration of $\mathrm{Cr}$, which is defined as maximum concentration of $\mathrm{Cr}$ not effecting bacterial growth.

\section{TOLERANCE TO OTHER HEAVY METALS AND NaCl}

All the isolated Cr-resistant bacteria were also exposed to different heavy metals $(\mathrm{Cd}, \mathrm{Cu}, \mathrm{Pb}$, and $\mathrm{Zn})$ and $\mathrm{NaCl}$ to determine their tolerance to the heavy metals and $\mathrm{NaCl}$ as described earlier (Sagar et al., 2012). Briefly, all the isolated rhizosphere and endophytic bacteria were streaked on LB agar media supplemented with different metals at different concentrations: $\mathrm{CdCl}_{2}(100 \mathrm{mg}$ $\left.\mathrm{l}^{-1}\right), \mathrm{CuCl}_{2}\left(100 \mathrm{mg} \mathrm{l}^{-1}\right), \mathrm{PbNO}_{3}\left(100 \mathrm{mg} \mathrm{l}^{-1}\right), \mathrm{ZnSO}_{4}(100 \mathrm{mg}$ $\left.1^{-1}\right)$ and $\mathrm{NaCl}(1 \mathrm{M}, 2 \mathrm{M}, 3 \mathrm{M}$, and $3.5 \mathrm{M})$. As the concentration of most of the heavy metals in the tannery effluent contaminated soil is below $100 \mathrm{mg} \mathrm{kg}^{-1}$, therefore, isolated bacterial strains were tested at $100 \mathrm{mg} \mathrm{kg}^{-1}$ of the heavy metals for their possible application in bacterial assisted phytoremediation of tannery effluent contaminated soil. 


\section{DETERMINATION OF PLANT GROWTH-PROMOTING PROPERTIES OF THE ISOLATED BACTERIA}

Different plant growth-promoting activities, such as 1aminocyclopropane-1-carboxylate (ACC) deaminase, siderophore and indole acetic acid (IAA) production and solubilize phosphorous were determined in all the isolated bacteria using the protocols as described earlier (Naveed et al., 2014). Briefly, ACC deaminase activity of the isolates was tested on minimal medium containing $0.7 \mathrm{~g} \mathrm{ACC} \mathrm{L}^{-1}$ as sole nitrogen source. Phosphate solubilization activity was determined by the formation of clear zone around bacterial growth on Pikovskaya's agar medium. Bacterial isolates were assayed for siderophore production on the Chrome azurol S (CAS) agar medium. The IAA production activity was determined using Salkowski reagent.

\section{EFFECT OF INOCULATION OF BACTERIA ON PLANT GROWTH}

Three different endophytic bacterial strains (Pantoea stewartii strain ASI11, Microbacterium arborescens strain HU33 and Enterobacter sp. strain HU38) were grown in LB broth overnight and cells were recovered by centrifugation and re-suspended in $0.9 \%(\mathrm{w} / \mathrm{v}) \mathrm{NaCl}$ solution. These bacteria exhibited Cr-resistance as well as plant growth-promoting activities. The compatibility of these three strains was tested by cultivating together on LB medium for $24 \mathrm{~h}$ and then plating serial dilutions of the culture on LB plates. Three different colonies, corresponding to ASI11, HU33, and HU38, could be isolated from LB plates, showing compatibility between the selected strains (data not shown). Ryegrass was shown to tolerate $\mathrm{Cr}$ and other heavy metals contamination in previous experiments (Duquène et al., 2009; Chigbo and Batty, 2013; Lou et al., 2013) and was therefore chosen as experimental plant. Surface sterilized seeds (200) of ryegrass were sown in the tannery effluent contaminated soil $(\mathrm{Cr}$ content, $2243 \mathrm{mg} \mathrm{kg}^{-1}$; $\mathrm{pH} 7.11 ; \mathrm{Na} 10370 \mathrm{mg} \mathrm{kg}^{-1} ; \mathrm{Cl} 4410 \mathrm{mg}$ $\mathrm{kg}^{-1} ; \mathrm{SO}_{4} 1081 \mathrm{mg} \mathrm{kg}^{-1} ; \mathrm{PO}_{4} 30 \mathrm{mg} \mathrm{kg}{ }^{-1} ; \mathrm{NO}_{3} 657 \mathrm{mg} \mathrm{kg}^{-1}$ ) in plastic pots $\left(1.5 \mathrm{~kg}\right.$ soil pot $\left.^{-1}\right)$ and bacterial inoculum was applied individually as well as in combination over the soil surface immediately after sowing the seeds as described earlier (Afzal et al., 2013). Before sowing, the soil was treated with $50 \mathrm{ml}$ inoculant suspension (app. $10^{10} \mathrm{cfu} / \mathrm{ml}$ ) containing mixture of ASI11, HU33, and $\mathrm{HU} 38$ or sterile $0.9 \% \mathrm{NaCl}$ solution. The combined inoculum containing equal numbers of each strain. Our previous experiments showed that inoculum density affects bacterial survival, colonization and phytoremediation efficacy, and maximum phytoremediation achieved at high inoculum density. Therefore, in this study, high density inoculum $\left(10^{10} \mathrm{cfu} / \mathrm{ml}\right)$ was used instead low inoculum density $\left(10^{7}-10^{8} \mathrm{cfu} / \mathrm{ml}\right)$. Treatment without bacterial inoculation was set as control. The pots were put under ambient conditions of temperature and light (1st March 2014-30th May 2014) in the vicinity of National Institute for Biotechnology and Genetic Engineering (NIBGE), Faisalabad, Pakistan. Percentage seed germination was determined after 1 week of sowing. After 3 months, plants were harvested, root and shoot length and dry weight were determined. Bacterial population sizes in the rhizosphere and endosphere of ryegrass were determined by plate count method on LB medium containing $500 \mathrm{mg} \mathrm{L}^{-1} \mathrm{Cr}$ as $\mathrm{Cr}_{2}\left(\mathrm{SO}_{4}\right)_{3}$ as described earlier (Afzal et al., 2012). Thirty colonies of each treatment were randomly picked and the identity of isolates with the inoculant strain was confirmed by restriction fragment length polymorphism (RFLP) analysis of the 16S-23S rRNA intergenic spacer region (IGS) (Andria et al., 2009). Isolates and inoculant strains had identical restriction patterns. Bulk soil, root and shoot samples were analyzed for $\mathrm{Cr}$ and other heavy metals as described earlier (Afzal et al., 2014c).

\section{STATISTICAL ANALYSIS}

SPSS software package version 17.0 (SPSS, Inc., Chicago, IL) was used for analyzing data for seed germination, shoot and root length and weight. The data (three replicates of each treatment) were subjected to analysis of variance (ANOVA), and the means [ \pm standard deviation (SD)] were compared using Duncan's multiple range test. Soil heavy metal concentrations were compared with One-Way of ANOVA. Plant heavy metal concentrations were analyzed by a paired $t$-test using Statistix Version 8.1; Statistix, Tallahasee, Florida, USA. Microbial enumeration data were subjected to Two-Way ANOVA. Mean separation was done using LSD at $p=0.05$.

\section{RESULTS \\ HEAVY METALS CONTENTS IN SOIL AND PLANT}

Heavy metal concentrations were significantly higher $(p=0.0309$ and 0.0280 , respectively) in the rhizosphere than in roots and shoots (Table 1). Similarly, heavy metal concentrations were significantly higher $(p=0.0096)$ in roots as compared to shoots. Based on mean values, heavy metals in the rhizospheric soil of $P$. juliflora follow the declining concentration $\left(\mathrm{mg} \mathrm{kg}^{-1}\right)$ order: $\mathrm{Cr}(2542)>\mathrm{Fe}(154)>\mathrm{Cu}(72)>\mathrm{Cd}(37)>\mathrm{Ni}(30)>\mathrm{Co}(28)>\mathrm{Pb}$ (22) $>\mathrm{Zn}(17)>\mathrm{Mn}(13)$.

\section{CULTURABLE BACTERIA IN THE RHIZOSPHERE AND ENDOSPHERE OF P. JULIFLORA}

Among all the isolates on the LB plates, 78 colonies were chosen according to their morphological differences and were differentiated into 26 groups according to their 16S-23S rRNA IGS RFLP patterns. A representative isolate of each IGS type was identified by partial $16 \mathrm{~S}$ rRNA gene sequencing. The 26 isolates belonged to different genera and the predominant genera included Bacillus, Staphylococcus and Aerococcus (Table 2). A higher number of genera were obtained from the endosphere than the rhizosphere, and among the endophytic bacteria 95\% were isolated from the shoot interior, whereas only $5 \%$ were obtained from the root interior.

\section{Cr-RESISTANCE OF THE ISOLATED BACTERIAL STRAINS}

All isolated rhizosphere and endophytic bacteria were able to grow at concentration $500 \mathrm{mg} \mathrm{L}^{-1} \mathrm{Cr}$ and could be considered resistant to this metal. It is important to note that only four bacteria (Pseudomonas aeruginosa sp. strain PJRS20, Pantoea stewartii sp. strain ASI11, Microbacterium arborescens sp. strain HU33 and Enterobacter sp. strain HU38) were able to grow at higher concentration of $\mathrm{Cr}\left(3000 \mathrm{mg} \mathrm{L}^{-1}\right)$. The maximum tolerable concentration of $\mathrm{Cr}$ for each isolate is shown in Table 3 .

\section{RESISTANCE TO OTHER HEAVY METALS AND NaCI}

Most of the isolated rhizosphere and endophytic bacteria exhibited tolerance to different heavy metals $(\mathrm{Cd}, \mathrm{Cu}, \mathrm{Pb}$, and $\mathrm{Zn})$ and 
Table 1 | The concentration of different heavy metals present in the bulk soil, rhizosphere, root and shoot of Prosopis juliflora growing on the tannery effluent contaminated soil.

\begin{tabular}{|c|c|c|c|c|c|c|c|c|c|}
\hline & Cd mg kg ${ }^{-1}$ & Co $\mathrm{mg} \mathrm{kg}^{-1}$ & Cr mg kg ${ }^{-1}$ & Cu mg kg & Fe $\mathrm{mg} \mathrm{kg}^{-1}$ & Mn mg kg ${ }^{-1}$ & $\mathrm{Ni} \mathbf{m g ~ \mathbf { k g } ^ { - 1 }}$ & $\mathrm{Pb} \mathrm{mg} \mathrm{kg}^{-1}$ & $\mathrm{Zn} \mathrm{mg} \mathrm{kg}{ }^{-1}$ \\
\hline Rhizosphere & $37(3.3)$ & $28(4.4)$ & 2542 (136) & $72(5.3)$ & $154(10)$ & $13(1.4)$ & $30(4.7)$ & $22(3.8)$ & $17(1.8)$ \\
\hline Shoot & $15(1.8)$ & $12(1.9)$ & 284 (37) & $19(1.4)$ & $58(5.1)$ & $7(0.6)$ & $13(1.5)$ & $12(1.1)$ & $12(1.4)$ \\
\hline
\end{tabular}

Each value is the mean of three replicates, the standard error of three replicates is presented in parentheses.

Table 2 | The diversity of bacteria isolated from the rhizosphere (RH), root interior (RI) and shoot interior (SI) of Prosopis juliflora growing on the tannery effluent contaminated soil.

\begin{tabular}{|c|c|c|c|c|}
\hline Strain name & Plant compartment & NCBI accession number & $\begin{array}{l}\text { Most closely related } \\
\text { species (sequence similarity, \%) }\end{array}$ & $\begin{array}{l}\text { Length (bp) of 16S rRNA } \\
\text { gene sequenced }\end{array}$ \\
\hline PJSI1 & SI & KJ999602 & Staphylococcus saprophyticus (99) & 1445 \\
\hline PJSI13 & SI & KJ999604 & Ochrobactrumintermedium (99) & 1351 \\
\hline PJRS17 & $\mathrm{RH}$ & KJ999605 & Arthrobacter sp. (99) & 1404 \\
\hline PJRS20 & $\mathrm{RH}$ & KJ999614 & Pseudomonas aeruginosa (99) & 1426 \\
\hline PJRI21 & $\mathrm{RH}$ & KM067905 & Bacillus licheniformis(99) & 776 \\
\hline PJSI41 & $\mathrm{SI}$ & KJ999610 & Bacillus pumilus (99) & 820 \\
\hline PJSI46 & $\mathrm{SI}$ & KJ999611 & Staphylococcus sp. (100) & 1102 \\
\hline PJSI34 & $\mathrm{SI}$ & KJ999607 & Aerococcus sp. (99) & 1128 \\
\hline PJSI9 & SI & KJ999613 & Staphylococcus epidermidis (99) & 1136 \\
\hline ASI14 & SI & KJ933400 & Ochrobactrum sp. (99) & 1094 \\
\hline SISI43 & $\mathrm{SI}$ & KJ933406 & Bacillus aerophilus (100) & 1434 \\
\hline PJRI24 & $\mathrm{RI}$ & KM067906 & Staphylococcus sp. (99) & 926 \\
\hline RSA27 & $\mathrm{RH}$ & KJ933401 & Bacillus licheniformis (99) & 1105 \\
\hline HU33 & $\mathrm{SI}$ & KJ933403 & Microbacteriumarborescens (99) & 1082 \\
\hline PASI10 & $\mathrm{SI}$ & KJ933398 & Aerococcusviridans (100) & 1122 \\
\hline PJSI37 & $\mathrm{SI}$ & KJ999609 & Brevundimonasvesicularis (99) & 1111 \\
\hline HU38 & SI & KJ933404 & Enterobacter sp. (99) & 1426 \\
\hline SISI39 & SI & KJ933405 & Bacillus aquimaris (99) & 1440 \\
\hline PJRS31 & $\mathrm{SI}$ & KJ999612 & Pseudomonas sp. (99) & 1427 \\
\hline RSAUK31 & $\mathrm{RH}$ & KJ933402 & Pseudomonas stutzeri (99) & 1104 \\
\hline
\end{tabular}

$\mathrm{NaCl}$ (Table 3). Three isolates exhibited tolerance to all the tested heavy metals $\left(100 \mathrm{mg} \mathrm{l}^{-1}\right)$. Strain ASI11 (99\% 16S rRNA gene identity to $P$. stewartii), strain HU33 (99\% 16S rRNA gene identity to $M$. arborescens) and strain HU38 (99\% 16S rRNA gene identity to Enterobactor $\mathrm{sp}$.) showed maximum $\left(300 \mathrm{mg} \mathrm{l}^{-1}\right)$ resistance toward $\mathrm{As}, \mathrm{Cd}, \mathrm{Pb}$, and $\mathrm{Zn}$ (data not shown). The growth of the isolates in the presence of $\mathrm{NaCl}$ was also evaluated. All the isolated bacteria were able to grow at $1 \mathrm{M}\left(58 \mathrm{~g} \mathrm{l}^{-1}\right) \mathrm{NaCl}$, only four isolates showed resistance to higher concentration of $\mathrm{NaCl}$, i.e., $3 \mathrm{M}$ $\left(174 \mathrm{~g} \mathrm{l}^{-1}\right)$, and none of them showed tolerance to $3.5 \mathrm{M}(203 \mathrm{~g}$ $\left.1^{-1}\right) \mathrm{NaCl}$.

\section{PLANT GROWTH-PROMOTING ACTIVITIES}

Most of the isolated strains exhibited one or more plant growthpromoting activities (Table 4). Only four shoot endophytes did not exhibit any tested plant growth-promoting activity. Eighteen strains exhibited ACC deaminase activity, 10 showed phosphorous solubilization activity, 7 showed IAA production potential and 11 were able to produce siderophores. Three isolates (P. stewartii strain ASI11, M. arborescens strain HU33 and Enterobacter sp. strain HU38) which exhibited all four tested plant growthpromoting activities as well as tolerance to higher levels of heavy metals and salt were selected for further analysis. 
Table 3 | Heavy metal and $\mathrm{NaCl}$ tolerance of the bacteria isolated from the rhizosphere and endosphere of Prosopis juliflora growing on tannery effluent contaminated soil.

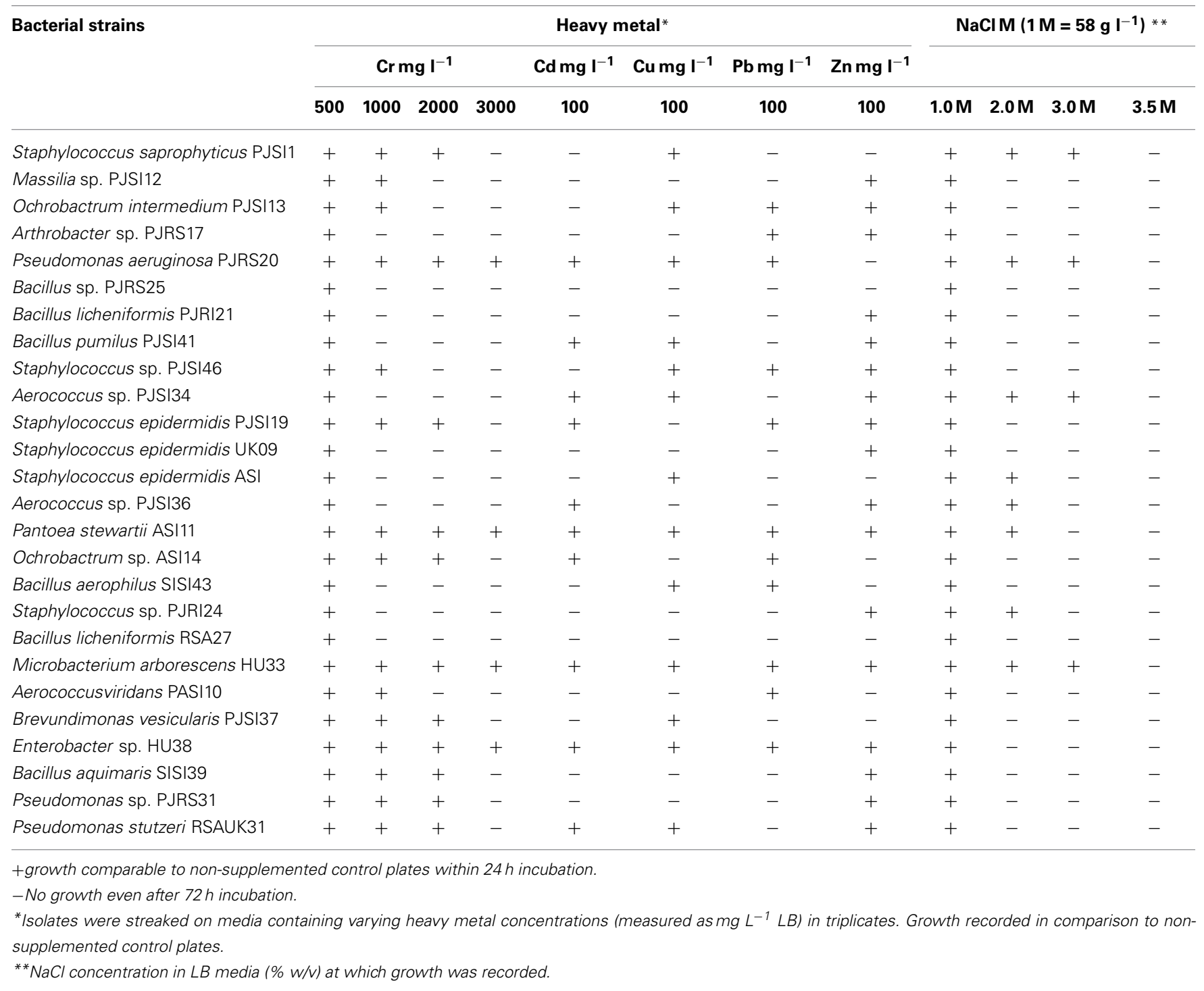

\section{EFFECT OF BACTERIAL INOCULATION ON PLANT GROWTH AND PHYTOREMEDIATION EFFICACY}

The effect of the isolated endophytic bacteria on growth of ryegrass vegetated in the tannery effluent contaminated soil was evaluated in a pot experiment. Comparatively less seed germination, shoot and root length and weight were obtained by the plants vegetated in the tannery effluent contaminated soil than the plants vegetated in agricultural soil (Table 5). Generally, bacterial inoculation improved seed germination, root and shoot length and weight. However, the application of a combination of three strains was found more efficient as compared to single-strain inoculum. Moreover, bacterial inoculation enhanced the accumulation of $\mathrm{Cr}$ in the root and shoot of ryegrass (Table 6). Maximum $\mathrm{Cr}$ accumulation was observed in the root and shoot of the plants inoculated with the multi-strain inoculation. The inoculated bacteria showed better persistence in the root and shoot than in the rhizosphere and maximum persistence was observed when the strains were applied in combination (Figure 1).

\section{DISCUSSION}

Although plants need some heavy metals as essential micronutrients, their excess in soil inhibits plant growth. The heavy metal tolerating capacity of plants mainly depends on plant species or genotype and the concentration of specific heavy metals in the environment (Pulford and Watson, 2003; Jamal, 2006; Leitenmaier and Küpper, 2013). There are no standards of heavy metals concentration in soil set by Pakistan. However, the limit of soil $\mathrm{Cr}$ in agricultural land, residential area, and commercialindustrial area were 500,600 , and $800 \mathrm{mg} \mathrm{kg}^{-1}$ in Germany and 750,250 , and $800 \mathrm{mg} \mathrm{kg}^{-1}$ in Canada, respectively (Balasoiu et al., 2001). In Canada, the allowed concentration of $\mathrm{Cd}, \mathrm{Ni}, \mathrm{Pb}$ and $\mathrm{Zn}$ in agricultural soil are $3,50,150,200$, and $600 \mathrm{mg} \mathrm{kg}^{-1}$ soil. In this study, high concentration of $\mathrm{Cr}$ and other heavy metals was 
Table 4 | Plant growth promoting activities of bacteria isolated from the rhizosphere, root interior and shoot interior of Prosopis juliflora growing on the tannery effluent contaminated soil.

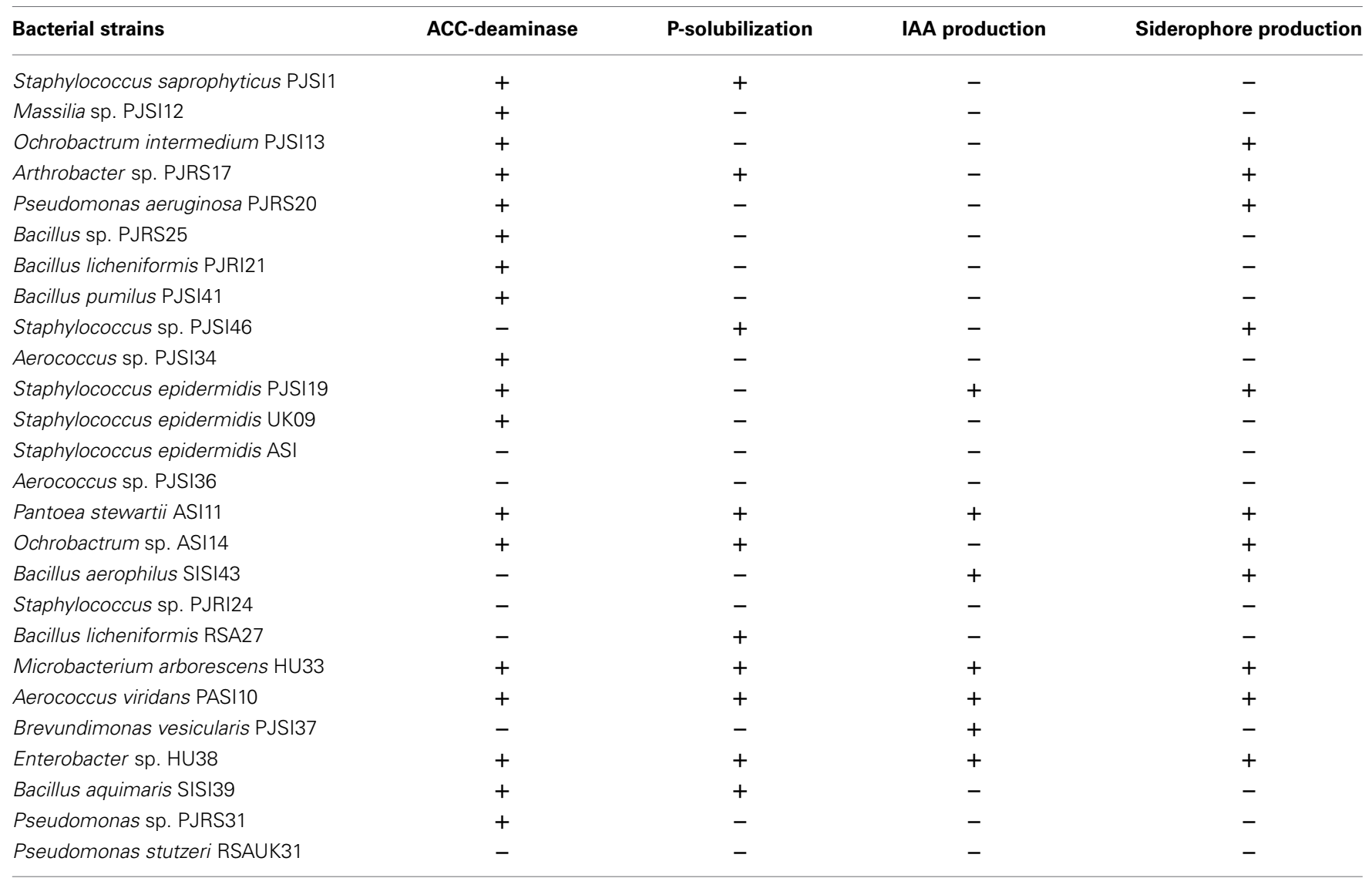

Table 5 | Effect of bacterial inoculation on seed germination, root and shoot length and dry weight of ryegrass vegetated on the tannery effluent contaminated soil.

\begin{tabular}{|c|c|c|c|c|c|}
\hline Treatment & $\begin{array}{l}\text { Seed germination } \\
(\%)\end{array}$ & \multicolumn{2}{|c|}{ Root } & \multicolumn{2}{|c|}{ Shoot } \\
\hline Control & $80(3.5)^{a}$ & $29.6(1.2)^{\mathrm{a}}$ & $61(3.8)^{\mathrm{a}}$ & $65(4.3)^{\mathrm{a}}$ & $29(1.4)^{\mathrm{a}}$ \\
\hline Contaminated soil & $53(2.2)^{d}$ & $15.6(1.6)^{d}$ & $31(2.7)^{d}$ & $34(3.5)^{d}$ & $15(0.7)^{d}$ \\
\hline Pantoea stewartii ASI11 & $62(2.6)^{c}$ & $20.5(0.9)^{c}$ & $37(3.2)^{\mathrm{cd}}$ & $40(2.8)^{c}$ & $21(1.1)^{c}$ \\
\hline Enterobacter sp. HU38 & $65(2.8)^{c}$ & $19.4(1.1)^{c}$ & $41(2.9)^{\mathrm{c}}$ & $41(3.4)^{\mathrm{c}}$ & $19(0.8)^{c}$ \\
\hline
\end{tabular}

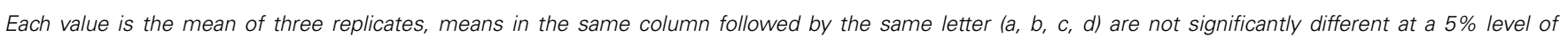
significance, the standard error of three replicates is presented in parentheses.

${ }^{*}$ Mixture of Pantoea stewartii ASI11, Microbacterium arborescens HU38, and Enterobacter sp. HU33.

observed in the rhizosphere, root, and shoot of $P$. juliflora growing on the tannery effluent contaminated soil (Table 1). Several earlier studies also reported that this plant can accumulate high concentration of different metals in its roots and shoots (Rai et al., 2004; Senthilkumar et al., 2005). This might be one of the reasons that $P$. juliflora hosts several bacteria in its rhizosphere and endosphere which can tolerate high concentration of heavy metals.
In the present study, a higher richness of culturable $\mathrm{Cr}$ resistant bacteria were found in the endosphere than in the rhizosphere and the predominant genera were Bacillus, Staphylococcus and Aerococcus. This might be due to better nutrients and environmental conditions inside the plant tissues than in the soil (Compant et al., 2010; Afzal et al., 2013), but it may be also due to better culturability of endophytes. Another possible reason could be higher concentrations of different toxic heavy metals in the 
Table 6 | Effect of bacterial inoculation on the accumulation of $\mathrm{Cr}$ in the root and shoot of ryegrass vegetated on the tannery effluent contaminated soil.

\begin{tabular}{|c|c|c|c|}
\hline Treatment & Soil (Cr mg kg ${ }^{-1}$ ) & Root (Cr mg kg ${ }^{-1}$ ) & Shoot $\mathrm{Cr} \mathbf{m g ~ k g}{ }^{-1}$ ) \\
\hline Pantoea stewartii ASI11 & $1552(46)^{b}$ & $435(10)^{b}$ & $240(9)^{b}$ \\
\hline Microbacterium arborescens HU33 & $1596(62)^{b}$ & $380(16)^{b}$ & $222(7)^{b}$ \\
\hline Consortium* & $1250(37)^{\mathrm{C}}$ & $598(13)^{a}$ & $356(5)^{a}$ \\
\hline
\end{tabular}

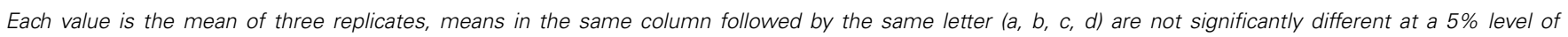
significance, the standard error of three replicates is presented in parentheses.

${ }^{*}$ Mixture of Pantoea stewartii ASI11, Microbacterium arborescens HU38, and Enterobacter sp. HU33.

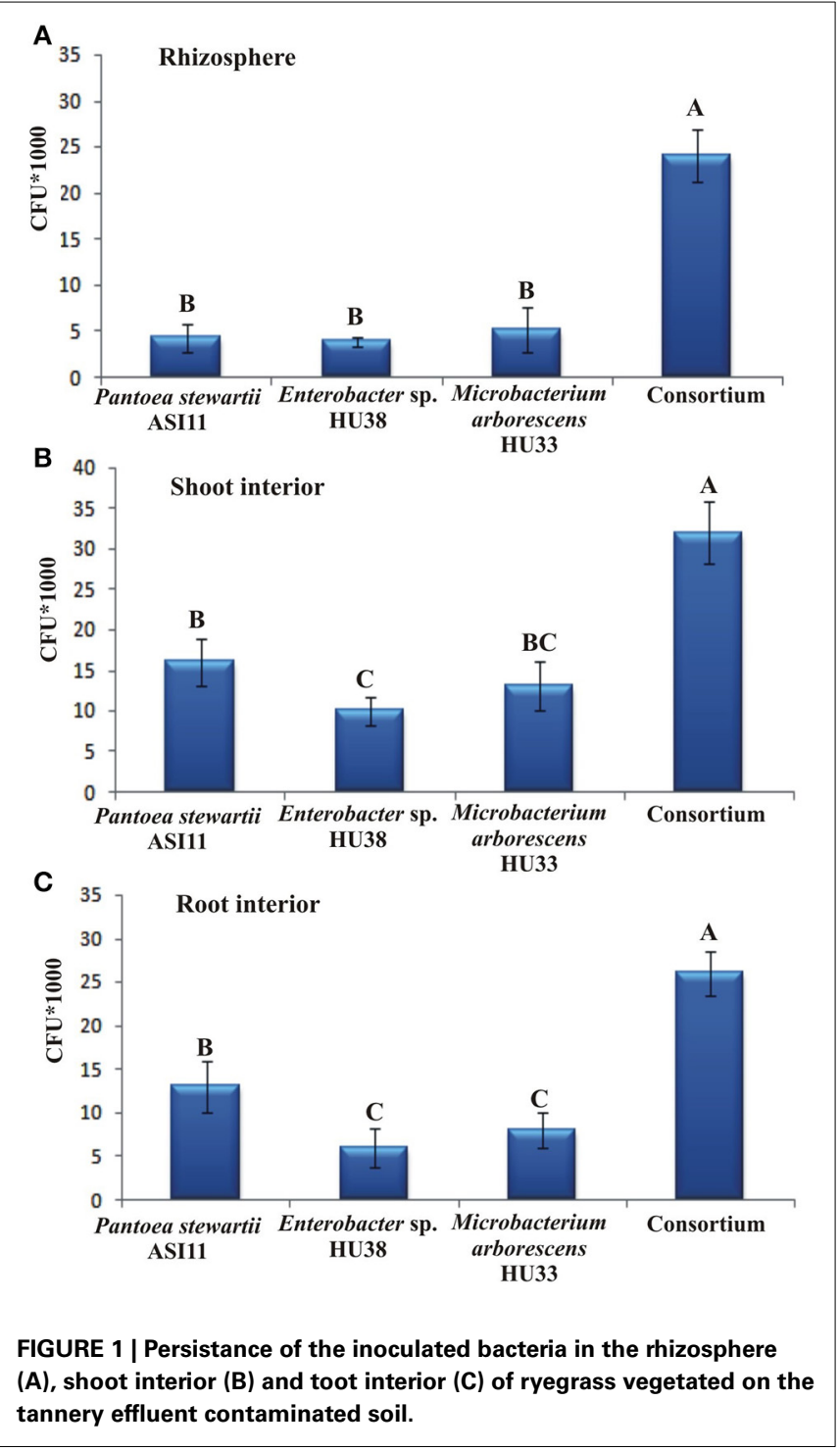

soil than within plant tissues. Several studies showed that metals influence microorganisms by adversely affecting their growth, morphology and biochemical activities, resulting in a decrease in their biomass and numbers (Giller et al., 1998; Abou-Shanab et al., 2005). Mostly, endophytes were different from rhizosphere strains and also roots and shoots hosted distinct taxa. Only few strains were isolated from the rhizosphere of $P$. juliflora, such as strain PJRS17 (99\% 16S rRNA gene identity to Arthrobacter sp.), strain PJRS20 (99\%16S rRNA gene identity to Pseudomonas aeruginosa), strain PJRI21 (99\% 16S rRNA gene identity to Bacillus licheniformis), strain RSA27 (99\% 16S rRNA gene identity to Bacillus licheniformis) and strain RSAUK31 (99\% 16S rRNA gene identity to Pseudomonas stutzeri) as shown in Table 2. It has been reported that most endophytes originate from the rhizosphere (Sessitsch et al., 2002; Compant et al., 2010), however, the plant apoplast offers different growth conditions and therefore different strains efficiently colonize the plant interior.

Tolerance of the isolates toward $\mathrm{Cr}$ was the first parameter evaluated, and all isolates were able to tolerate this metal up to $500 \mathrm{mg}$ $\mathrm{I}^{-1}$. $\mathrm{Cr}$, together with $\mathrm{Cd}, \mathrm{Cu}, \mathrm{Pb}$, and $\mathrm{Zn}$ are the main contaminants in the tannery effluent contaminated soil (Khan, 2001; Tariq et al., 2009; Afzal et al., 2014a). Among the isolates, four strains showed resistance to very high concentration of $\mathrm{Cr}\left(3000 \mathrm{mg} \mathrm{l}^{-1}\right)$ which include Pseudomonas aeruginosa sp. strain PJRS20, Pantoea stewartii sp. strain ASI11, Microbacterium arborescens sp. strain HU33 and Enterobacter sp. strain HU38. In many other studies Cr-resistant bacteria were also isolated, however, they exhibited resistance to comparatively lower concentration of this metal (Srinath et al., 2002; Viti et al., 2003; Chatterjee et al., 2009). The Cr-resistant isolates can also tolerate other heavy metals and $\mathrm{NaCl}\left(174 \mathrm{~g} \mathrm{l}^{-1}\right)$, suggesting the potential use of these bacteria in the bacterial-assisted phytoremediation of soil contaminated with heavy metals and also for restoration of the saline soil.

Most of the isolated bacteria also exhibited one or more plant growth-promoting activities. It could be one of the possible reasons of the survival and growth of $P$. juliflora in the highly contaminated soil. Among the isolates, $69 \%$ exhibited ACC deaminase activity, which is an important function of plant growthpromoting bacteria, it causes the reduction of stress ethylene in plants (Glick, 2010; Glick and Stearns, 2011; Sessitsch et al., 2013). Comparatively, a low number of isolated strains showed IAA production (27\%), P-solubilization (35\%) and siderophore production $(42 \%)$. IAA production enhances the root surface area and nutrients uptake by plants (Shagol et al., 2014). The phosphate-solubilizing activity can enhance the availability of phosphorous and heavy metals to the plants (Fitz and Wenzel, 2002). Three strains (P. stewartii strain ASI11, M. arborescens 
strain HU33 and Enterobacter sp. strain HU38) exhibiting multiple plant growth promoting potential as well as tolerance to higher levels of heavy metals and salt were selected for use in vitro plant-inoculation assay. Altogether, plant growth-promoting bacteria have the potential to improve plant growth and may either increase uptake of heavy metals by plants or stabilize heavy metals in soils preventing further uptake (Glick, 2010; Rajkumar et al., 2012; Sessitsch et al., 2013).

In this study, comparatively less seed germination and root and shoot development was observed with plants cultivated in the tannery effluent contaminated soil as compared to the plants vegetated in control agricultural soil (Table 5). The presence of $\mathrm{Cr}$ and other heavy metals in soil reduces seed germination and plant growth (Khan, 2001; Sagar et al., 2012; Carvalho et al., 2013; Lin et al., 2014). Despite the toxic effects of heavy metals present in the contaminated soil, inoculation of Cr-resistant plant growth-promoting bacteria increased seed germination and root and shoot development. Particularly, bacterial consortium comprising three individual strains improved plant growth and development to a greater extent than single strain application. Similarly, it was found that bacterial inoculation reduced Cr toxicity and improved seed germination and plant growth (Chatterjee et al., 2009). In this study, the ability of the inoculated endophytic bacteria to improve plant growth in the heavy metal contaminated soil might be due to the combined effect of heavy metal tolerance ability as well as plant growth-promoting activities (Glick, 2010).

Bacterial populations of inoculated strains in the rhizosphere and endosphere of ryegrass were determined and we found that the inoculated strains were able to persist in the rhizosphere and endosphere of the plant vegetated in the tannery effluent contaminated soil (Figure 1). Although Cr-resistant bacteria were applied on the soil surface, high numbers of bacterial cells were found within plant tissues. The plant interior might provide a more protective and less toxic environment than the rhizosphere (Afzal et al., 2012). Similarly in previous studies, applied endophytic bacteria exhibited higher levels of colonization and activity in the endosphere than the rhizosphere (Andria et al., 2009; Afzal et al., 2011; Yousaf et al., 2011).

In this study, ryegrass was found to be able to remove $\mathrm{Cr}$ and other heavy metals from the tannery effluent contaminated soil. The application of Cr-resistant plant growth-promoting endophytic bacteria to ryegrass further enhanced the removal of $\mathrm{Cr}$ (Table 6) and other heavy metals (data not shown) from the soil. The maximum accumulation of heavy metals was found in the roots and shoots of the plants inoculated with the combination of three bacterial strains. Similarly, earlier studies reported that the inoculation of Cr-resistant plant growth-promoting bacteria enhanced the heavy metals uptake by plants (Faisal and Hasnain, 2006; Rajkumar et al., 2006; Wani et al., 2008; Arzanesh et al., 2009). Enhanced heavy metals translocation in plant tissues can be attributed to the IAA production and phosphate solubilization activity of the inoculated strains (Husen, 2013). The present study suggests that the use of Cr-resistant plant growth-promoting bacteria protects the plant against the inhibitory effects of heavy metals present in the tannery effluent contaminated soil and facilitates the transportation of heavy metals from soil into above ground plant biomass.
Plant-bacteria partnerships can be exploited to enhance phytoremediation efficiency of soil and water contaminated with organic and inorganic pollutants (Weyens et al., 2009; Khan et al., 2013; Afzal et al., 2014b). The beneficial effects of heavy metalresistant and plant growth-promoting bacteria include reduced heavy metals toxicity and accelerated root development, resulting in better access to nutrients and water and thus faster initial growth, leading to enhanced remediation of contaminated soil and water and environmentally and economically sustainable plant biomass production. Improved yields on contaminated land might also reduce the need to clear and use additional areas of land for food, feed fiber and biofuel feedstock production for a growing world population, consequentially saving native ecosystems and biodiversity. Overall, the combined use of plants and bacteria can act as decontaminators by improving phytoremediation or protecting the food chain by decreasing the levels of pesticide residues in crops.

We have found that $P$. juliflora hosted 26 culturable Crresistant bacteria in its endosphere and rhizosphere and their inoculation to ryegrass improved plant growth and the remediation of tannery effluent contaminated soil, suggesting their potential use in the remediation of heavy metal contaminated soil. The stimulatory effects of Cr-resistant plant growth-promoting endophytic bacteria on ryegrass growth might be due to the additive effects of different plant growth-promoting properties of the isolated endophytic bacteria. Further plant-inoculation experiments (pair-wise in different combinations) are needed to better understand the stimulatory effects of the combined inoculation strategy. The very high level of metal tolerance of the isolated rhizosphere and endophytic bacteria of $P$. juliflora makes them interesting candidates for further studies on the genes involved in this tolerance. Plants growing on tannery effluent contaminated sites could be excellent ecosystems to isolate bacterial genes involved in metal resistance and/or plant growth promotion.

\section{ACKNOWLEDGMENTS}

This study was financially supported by Higher Education Commission (HEC, grant number 1997), Pakistan and International Foundation of Science (IFS) Sweden and Organisation for the Prohibition of Chemical Weapons (OPCW) (grant number W/5104-2). We acknowledge the support by a grant provided by the FWF (Austrian Science Foundation, grant no. P 24569-B25) to AS.

\section{REFERENCES}

Abou-Shanab, R. A., Ghozlan, H., Ghanem, K., and Moawad, H. (2005). Behaviour of bacterial populations isolated from rhizosphere of Diplachne fusca dominant in industrial sites. World J. Microb. Biot. 21, 1095-1101. doi: 10.1007/s11274004-0005-6

Afzal, M., Khan, Q. M., and Sessitsch, A. (2014b). Endophytic bacteria: prospects and applications for the phytoremediation of organic pollutants. Chemosphere 117, 232-242. doi: 10.1016/j.chemosphere.2014.06.078

Afzal, M., Khan, S., Iqbal, S., Mirza, M. S., and Khan, Q. M. (2013). Inoculation method affects colonization and activity of Burkholderia phytofirmans PsJN during phytoremediation of diesel-contaminated soil. Int. Biodeter. Biodegr. 85, 331-336. doi: 10.1016/j.ibiod.2013.08.022

Afzal, M., Shabir, G., Iqbal, S., Mustafa, T., Khan, Q. M., and Khalid, Z. M. (2014a). Assessment of heavy metal contamination in soil and groundwater at leather industrial area of Kasur, Pakistan. CLEAN Soil Air Water 42, 1133-1139. doi: 10.1002/clen.201100715 
Afzal, M., Shabir, G., Tahseen, R., Ejazul, I., Iqbal, S., Khan, Q. M., et al. (2014c). Endophytic Burkholderia sp. strain PsJN improves plant growth and phytoremediation of soil irrigated with textile effluent. CLEAN Soil Air Water 42, 1304-1310. doi: 10.1002/clen.201300006

Afzal, M., Yousaf, S., Reichenauer, T. G., Kuffner, M., and Sessitsch, A. (2011). Soil type affects plant colonization, activity and catabolic gene expression of inoculated bacterial strains during phytoremediation of diesel. J. Hazard. Mater. 186, 1568-1575. doi: 10.1016/j.jhazmat.2010.12.040

Afzal, M., Yousaf, S., Reichenauer, T. G., and Sessitsch, A. (2012). The inoculation method affects colonization and performance of bacterial inoculant strains in the phytoremediation of soil contaminated with diesel oil. Int. J. Phytorem. 14, 35-47. doi: 10.1080/15226514.2011.552928

Andrades-Moreno, L., Del Castillo, I., Parra, R., Doukkali, B., Redondo-Gómez, S., Pérez-Palacios, P., et al. (2014). Prospecting metal-resistant plant-growth promoting rhizobacteria for rhizoremediation of metal contaminated estuaries using Spartina densiflora. Environ. Sci. Pollut. Res. 21, 3713-3721. doi: 10.1007/s11356-013-2364-8

Andria, V., Reichenauer, T. G., and Sessitsch, A. (2009). Expression of alkane monooxygenase $(a l k B)$ genes by plant-associated bacteria in the rhizosphere and endosphere of Italian ryegrass (Lolium multiflorum L.) grown in diesel contaminated soil. Environ. Pollut. 157, 3347-3350. doi: 10.1016/j.envpol.2009.08.023

Arzanesh, M., Alikhani, H., Khavazi, K., Rahimian, H., and Miransari, M. (2009). In vitro growth of wheat (Triticum aestivum L.) seedlings inoculated with Azospirillum sp., under drought stress. Int. J. Bot. 5, 244-249. doi: 10.3923/ijb.2009.244.249

Balasoiu, C. F., Zagury, G. J., and Deschenes, L. (2001). Partitioning and speciation of chromium, copper, and arsenic in CCA-contaminated soils: influence of soil composition. Sci. Total Environ. 280, 239-255. doi: 10.1016/S00489697(01)00833-6

Benata, H., Mohammed, O., Noureddine, B., Abdelbasset, B., Abdelmoumen, H., Muresu, R., et al. (2008). Diversity of bacteria that nodulate Prosopis juliflora in the eastern area of Morocco. Syst. Appl. Microbiol. 31, 378-386. doi: 10.1016/j.syapm.2008.08.002

Capuana, M. (2011). Heavy metals and woody plants-biotechnologies for phytoremediation. iForest 4, 7-15. doi: 10.3832/ifor0555-004

Carvalho, M. T. V., Amaral, D. C., Guilherme, L. R. G., and Aarts, M. G. M. (2013). Gomphrena claussenii, the first South-American metallophyte species with indicator-like $\mathrm{Zn}$ and $\mathrm{Cd}$ accumulation and extreme metal tolerance. Front. Plant Sci. 4:180. doi: 10.3389/fpls.2013.00180

Chatterjee, S., Sau, G. B., and Mukherjee, S. K. (2009). Plant growth promotion by a hexavalent chromium reducing bacterial strain, Cellulosimicrobium cellulans KUCr3. World J. Microbiol. Biotechnol. 25, 1829-1836. doi: 10.1007/s11274-0090084-5

Chen, L., Luo, S., Xiao, X., Guo, H., Chen, J., Wan, Y., et al. (2010). Application of plant growth-promoting endophytes (PGPE) isolated from Solanum nigrum L. for phytoextraction of Cd-polluted soils. Appl. Soil Ecol. 46, 383-389. doi: 10.1016/j.apsoil.2010.10.003

Chigbo, C., and Batty, L. (2013). Effect of combined pollution of chromium and benzo (a) pyrene on seed growth of Lolium perenne. Chemosphere 90, 164-169. doi: 10.1016/j.chemosphere.2012.06.021

Compant, S., Clément, C., and Sessitsch, A. (2010). Plant growth-promoting bacteria in the rhizo- and endosphere of plants: their role, colonization, mechanisms involved and prospects for utilization. Soil Biol. Biochem. 42, 669-678. doi: 10.1016/j.soilbio.2009.11.024

Deans, J., Diagne, O., Nizinski, J., Lindley, D., Seck, M., Ingleby, K., et al. (2003). Comparative growth, biomass production, nutrient use and soil amelioration by nitrogen-fixing tree species in semi-arid Senegal. Forest Ecol. Manage. 176, 253-264. doi: 10.1016/S0378-1127(02)00296-7

Duquène, L., Vandenhove, H., Tack, F., Meers, E., Baeten, J., and Wannijn, J. (2009). Enhanced phytoextraction of uranium and selected heavy metals by Indian mustard and ryegrass using biodegradable soil amendments. Sci. Total Environ. 407, 1496-1505. doi: 10.1016/j.scitotenv.2008.10.049

Faisal, M., and Hasnain, S. (2006). Growth stimulatory effect of Ochrobactrum intermedium and Bacillus cereus on Vigna radiata plants. Lett. Appl. Microbiol. 43, 461-466. doi: 10.1111/j.1472-765X.2006.01977.x

Fitz, W. J., and Wenzel, W. W. (2002). Arsenic transformations in the soilrhizosphere-plant system: fundamentals and potential application to phytoremediation. J. Biotechnol. 99, 259-278. doi: 10.1016/S0168-1656(02)00218-3
Gadd, G. M. (2010). Metals, minerals and microbes: geomicrobiology and bioremediation. Microbiology 156, 609-643. doi: 10.1099/mic.0.037143-0

Gil-Cardeza, M. L., Ferri, A., Cornejo, P., and Gomez, E. (2014). Distribution of chromium species in a Cr-polluted soil: presence of $\mathrm{Cr}$ (III) in glomalin related protein fraction. Sci. Total Environ. 493, 828-833. doi: 10.1016/j.scitotenv.2014.06.080

Giller, K. E., Witter, E., and McGrath, S. P. (1998). Toxicity of heavy metals to microorganisms and microbial processes in agricultural soils. Soil Biol. Biochem. 30, 1389-1414. doi: 10.1016/S0038-0717(97)00270-8

Glick, B. R. (2010). Using soil bacteria to facilitate phytoremediation. Biotechnol. Adv. 28, 367-374. doi: 10.1016/j.biotechadv.2010.02.001

Glick, B. R., and Stearns, J. C. (2011). Making phytoremediation work better: maximizing a plant's growth potential in the midst of adversity. Int. J. Phytorem. 13, 4-16. doi: 10.1080/15226514.2011.568533

Husen, E. (2013). Screening of soil bacteria for plant growth promotion activities in vitro. Indonesian J. Agricul. Sci. 4, 27-31.

Jamal, S. N. (2006). Effect of aluminum and chromium on the growth and germination of mesquite (Prosopis juliflora swartz.) DC. Int. J. Environ. Sci. Technol. 3, 173-176. doi: 10.1007/BF03325922

Khan, A. G. (2001). Relationships between chromium biomagnification ratio, accumulation factor, and mycorrhizae in plants growing on tannery effluentpolluted soil. Environ. Int. 26, 417-423. doi: 10.1016/S0160-4120(01)00022-8

Khan, S., Afzal, M., Iqbal, S., and Khan, Q. M. (2013). Plant-bacteria partnerships for the remediation of hydrocarbon contaminated soils. Chemosphere 90 , 1317-1332. doi: 10.1016/j.chemosphere.2012.09.045

Kuffner, M., Puschenreiter, M., Wieshammer, G., Gorfer, M., and Sessitsch, A. (2008). Rhizosphere bacteria affect growth and metal uptake of heavy metal accumulating willows. Plant Soil 304, 35-44. doi: 10.1007/s11104-007-9517-9

Leitenmaier, B., and Küpper, H. (2013). Compartmentation and complexation of metals in hyperaccumulator plants. Front. Plant Sci. 4:374. doi: 10.3389/fpls.2013.00374

Lin, Y.-F., Severing, E., Te Lintel Hekkert, B., Schijlen, E., and Aarts, M. G. M. (2014). A comprehensive set of transcript sequences of the heavy metal hyperaccumulator Noccaea caerulescens. Front. Plant Sci. 5:261. doi: 10.3389/fpls.2014.00261

Lou, Y., Luo, H., Hu, T., Li, H., and Fu, J. (2013). Toxic effects, uptake, and translocation of $\mathrm{Cd}$ and $\mathrm{Pb}$ in perennial ryegrass. Ecotoxicology 22, 207-214. doi: 10.1007/s10646-012-1017-x

Ma, Y., Prasad, M., Rajkumar, M., and Freitas, H. (2011). Plant growth promoting rhizobacteria and endophytes accelerate phytoremediation of metalliferous soils. Biotechnol. Adv. 29, 248-258. doi: 10.1016/j.biotechadv.2010.12.001

Ma, Y., Rajkumar, M., and Freitas, H. (2009). Inoculation of plant growth promoting bacterium Achromobacter xylosoxidans strain Ax10 for the improvement of copper phytoextraction by Brassica juncea. J. Environ. Manage. 90, 831-837. doi: 10.1016/j.jenvman.2008.01.014

Mastretta, C., Taghavi, S., Van Der Lelie, D., Mengoni, A., Galardi, F., Gonnelli, C., et al. (2009). Endophytic bacteria from seeds of Nicotiana tabacum can reduce cadmium phytotoxicity. Int. J. Phytorem. 11, 251-267. doi: $10.1080 / 15226510802432678$

Naveed, M., Mitter, B., Yousaf, S., Pastar, M., Afzal, M., and Sessitsch, A. (2014). The endophyte Enterobacter sp. FD17: a maize growth enhancer selected based on rigorous testing of plant beneficial traits and colonization characteristics. Biol. Fertil. Soils 50, 249-262. doi: 10.1007/s00374-013-0854-y

Pulford, I., and Watson, C. (2003). Phytoremediation of heavy metal-contaminated land by trees. Environ. Int. 29, 529-540. doi: 10.1016/S0160-4120(02)00152-6

Qureshi, H., Arshad, M., and Bibi, Y. (2014). Invasive flora of Pakistan: a critical analysis. J. Biodiver. Environ. Sci. 4, 407-424.

Rai, U., Pandey, K., Sinha, S., Singh, A., Saxena, R., and Gupta, D. (2004) Revegetating fly ash landfills with Prosopis juliflora L.: impact of different amendments and Rhizobium inoculation. Environ. Int. 30, 293-300. doi: 10.1016/S0160-4120(03)00179-X

Rajkumar, M., Nagendran, R., Lee, K. J., Lee, W. H., and Kim, S. Z. (2006). Influence of plant growth promoting bacteria and $\mathrm{Cr}^{6+}$ on the growth of Indian mustard. Chemosphere 62, 741-748. doi: 10.1016/j.chemosphere.2005.04.117

Rajkumar, M., Sandhya, S., Prasad, M., and Freitas, H. (2012). Perspectives of plant-associated microbes in heavy metal phytoremediation. Biotechnol. Adv. 30, 1562-1574. doi: 10.1016/j.biotechadv.2012.04.011

Rasche, F., Velvis, H., Zachow, C., Berg, G., Van Elsas, J. D., and Sessitsch, A. (2006). Impact of transgenic potatoes expressing anti-bacterial agents on 
bacterial endophytes is comparable with the effects of plant genotype, soil type and pathogen infection. J. Appl. Ecol. 43, 555-566. doi: 10.1111/j.13652664.2006.01169.x

Reichman, S. (2014). Probing the plant growth-promoting and heavy metal tolerance characteristics of Bradyrhizobium japonicum CB1809. Eur. J. Soil Biol. 63 , 7-13. doi: 10.1016/j.ejsobi.2014.04.001

Sagar, S., Dwivedi, A., Yadav, S., Tripathi, M., and Kaistha, S. D. (2012). Hexavalent chromium reduction and plant growth promotion by Staphylococcus arlettae strain Cr11. Chemosphere 86, 847-852. doi: 10.1016/j.chemosphere.2011. 11.031

Sajjad, A., Saeed, S., and Bashir, M. A. (2012). Spatial variation in pollinator communities and productive performance of Prosopis juliflora (Fabaceae). J. Poll. Ecol. 8, 59-66.

Senthilkumar, P., Prince, W., Sivakumar, S., and Subbhuraam, C. (2005). Prosopis juliflora-A green solution to decontaminate heavy metal $(\mathrm{Cu}$ and $\mathrm{Cd})$ contaminated soils. Chemosphere 60, 1493-1496. doi: 10.1016/j.chemosphere.2005.02.022

Sessitsch, A., Kuffner, M., Kidd, P., Vangronsveld, J., Wenzel, W., Fallmann, K., et al. (2013). The role of plant-associated bacteria in the mobilization and phytoextraction of trace elements in contaminated soils. Soil Biol. Biochem. 60, 182-194. doi: 10.1016/j.soilbio.2013.01.012

Sessitsch, A., Reiter, B., Pfeifer, U., and Wilhelm, E. (2002). Cultivationindependent population analysis of bacterial endophytes in three potato varieties based on eubacterial and Actinomycetes-specific PCR of 16S rRNA genes. FEMS Microbiol. Ecol. 39, 23-32. doi: 10.1111/j.1574-6941.2002. tb00903.x

Shagol, C. C., Krishnamoorthy, R., Kim, K., Sundaram, S., and Sa, T. (2014). Arsenic-tolerant plant-growth-promoting bacteria isolated from arsenicpolluted soils in South Korea. Environ. Sci. Pollut. Res. 21, 9356-9365. doi: 10.1007/s11356-014-2852-5

Srinath, T., Verma, T., Ramteke, P., and Garg, S. (2002). Chromium (VI) biosorption and bioaccumulation by chromate resistant bacteria. Chemosphere 48 427-435. doi: 10.1016/S0045-6535(02)00089-9

Tariq, S. R., Shah, M. H., and Shaheen, N. (2009). Comparative statistical analysis of chrome and vegetable tanning effluents and their effects on related soil. J. Hazard. Mater. 169, 285-290. doi: 10.1016/j.jhazmat.2009.03.093

Tariq, S. R., Shah, M. H., Shaheen, N., Jaffar, M., and Khalique, A. (2008). Statistical source identification of metals in groundwater exposed to industrial contamination. Environ. Monit. Assess. 138, 159-165. doi: 10.1007/s10661-0079753-8

Usha, B., Venkataraman, G., and Parida, A. (2009). Heavy metal and abiotic stress inducible metallothionein isoforms from Prosopis juliflora (SW) DC show differences in binding to heavy metals in vitro. Mol. Genet. Genomics 281, 99-108. doi: $10.1007 / \mathrm{s} 00438-008-0398-2$

Varun, M., D’souza, R., Pratas, J., and Paul, M. (2011). Phytoextraction potential of Prosopis juliflora (Sw.) DC. with specific reference to lead and cadmium. Bull. Environ. Contam. Toxicol. 87, 45-49. doi: 10.1007/s00128-011-0305-0
Viti, C., Pace, A., and Giovannetti, L. (2003). Characterization of Cr(VI)-resistant bacteria isolated from chromium-contaminated soil by tannery activity. Curr. Microbiol. 46, 0001-0005. doi: 10.1007/s00284-002-3800-Z

Wani, P. A., Khan, M. S., and Zaidi, A. (2008). Chromium-reducing and plant growth-promoting Mesorhizobium improves chickpea growth in chromiumamended soil. Biotechnol. Lett. 30, 159-163. doi: 10.1007/s10529-007-9515-2

Weyens, N., Van Der Lelie, D., Taghavi, S., Newman, L., and Vangronsveld, J. (2009). Exploiting plant-microbe partnerships to improve biomass production and remediation. Trends Biotechnol. 27, 591-598. doi: 10.1016/j.tibtech.2009.07.006

Yousaf, S., Afzal, M., Reichenauer, T. G., Brady, C. L., and Sessitsch, A. (2011). Hydrocarbon degradation, plant colonization and gene expression of alkane degradation genes by endophytic Enterobacter ludwigii strains. Environ. Pollut. 159, 2675-2683. doi: 10.1016/j.envpol.2011.05.031

Yousaf, S., Andria, V., Reichenauer, T. G., Smalla, K., and Sessitsch, A. (2010b). Phylogenetic and functional diversity of alkane degrading bacteria associated with Italian ryegrass (Lolium multiflorum) and Birdsfoot trefoil (Lotus corniculatus) in a petroleum oil-contaminated environment. J. Hazard. Mater. 184, 523-532. doi: 10.1016/j.jhazmat.2010.08.067

Yousaf, S., Ripka, K., Reichenauer, T., Andria, V., Afzal, M., and Sessitsch, A. (2010a). Hydrocarbon degradation and plant colonization by selected bacterial strains isolated from Italian ryegrass and birdsfoot trefoil. J. Appl. Microbiol. 109, 1389-1401. doi: 10.1111/j.1365-2672.2010.04768.x

Zhu, L.-J., Guan, D.-X., Luo, J., Rathinasabapathi, B., and Ma, L. Q. (2014). Characterization of arsenic-resistant endophytic bacteria from hyperaccumulators Pteris vittata and Pteris multifida. Chemosphere 113, 9-16. doi: 10.1016/j.chemosphere.2014.03.081

Conflict of Interest Statement: The authors declare that the research was conducted in the absence of any commercial or financial relationships that could be construed as a potential conflict of interest.

Received: 22 September 2014; accepted: 09 December 2014; published online: 06 January 2015.

Citation: Khan MU, Sessitsch A, Harris M, Fatima K, Imran A, Arslan M, Shabir G, Khan QM and Afzal M (2015) Cr-resistant rhizo- and endophytic bacteria associated with Prosopis juliflora and their potential as phytoremediation enhancing agents in metal-degraded soils. Front. Plant Sci. 5:755. doi: 10.3389/fpls.2014.00755

This article was submitted to Plant Biotechnology, a section of the journal Frontiers in Plant Science.

Copyright (c) 2015 Khan, Sessitsch, Harris, Fatima, Imran, Arslan, Shabir, Khan and Afzal. This is an open-access article distributed under the terms of the Creative Commons Attribution License (CC BY). The use, distribution or reproduction in other forums is permitted, provided the original author(s) or licensor are credited and that the original publication in this journal is cited, in accordance with accepted academic practice. No use, distribution or reproduction is permitted which does not comply with these terms. 